\title{
MAIS TRÊS CASOS DE APLICAÇÃO DO BENEFICIUM COMPETENTIAE*
}

\author{
Ignácio Maria Poveda Velasco \\ Professor Doutor do Departamento de Direito Civil da \\ Faculdade de Direito da Universidade de São Paulo
}

Resumo:

De acordo com as fontes romanas, o devedor insolvente que sofria a bonorum venditio podia voltar a ser executado por seus credores ex ante gesto, a fim destes obterem dele plena satisfação de seus direitos. Em virtude, porém, de determinação edital, o falido gozava do beneficium competentiae, dentro do ano contado a partir da venditio. O benefício, neste caso, visaria apenas evitar que os demais credores ex ante gesto investissem inescrupulosamente contra o falido, sem um mínimo de humana compreensão. O favor não pouparia, contudo, ao devedor a nota infamante, uma vez que esta já recaíra sobre ele em decorrência do decretum que autorizara a bonorum venditio.

Tratamento mais benigno mereceu quem, em virtude de disposição de certa Lex Iulia de bonis cedendis, cedesse seus bens aos credores. Consciente de sua insolvência, o devedor podia, mediante solicitação ao magistrado, entregar seus bens aos credores, evitando assim o efeito infamante da execução patrimonial forçada e afastando a possibilidade de eventual execução pessoal que se abateria provavelmente sobre ele, caso seus bens não bastassem para a satisfação dos créditos.

Os filhos emancipados, deserdados e os que se abstivessem da herança gozavam, também, do benefício quando demandados por dividas contraídas enquanto se achavam in potestate. A concessão do benefício aos filhos nessas condições parece plenamente justificada e obedece a um critério de justiça.

Abstract:

According to the roman sources, the insolvent debtor that suffered the bonorum venditio could be re-executed by it's creditors ex ante gesto, in order to obtain from him full satisfaction of their rights. Due to the determination of "Edital" the insolvent had the beneficium competentiae, inside of the year counted starting from the venditio. The benefit, in this case, would just seek to avoid the other former creditors ex ante gesto to invest against the insolvent without scruples, without a minimum of human comprehension. The favour would not save, however, from the debtor the

* O presente trabalho dá seqüência aos artigos Algumas considerações à respeito do beneficium competentiae e $O$ beneficium competentiae do sócio (socius), publicados pelo autor na Revista da Faculdade de Direito da Universidade de São Paulo, respectivamente nos vs. 91 e 92. 
infamous note, once this had already incurred on him due to decretum that had authorized the bonorum venditio.

More benign treatment deserved who, in virtue of disposition of Lex lulia de bonis cedendis, gave its goods to its creditors. Conscious of its insolvency, the debtor could, by asking the judge, to give its goods to the creditors, avoiding that way the infamous effect of forced patrimonial execution and putting away the possibility of eventual personal execution that would probably fall on him, if his goods weren't enough to satisfy the credits.

The emancipated sons, deserted and the ones that abstained from the inheritance had, also, the benefit when demands by contracted debts while in potestate. The concession of the benefit to the sons in those conditions seems completely justified and obeys na approach of justice.

Unitermos: execução; condenação limitada; benefício.

1. O falido (venditio bonorum)

A doutrina é unânime ao mencionar, entre os devedores que gozavam do beneficium competentiae, aquele que sofrera a execução patrimonial forçada. ${ }^{~}$ As fontes, contudo, são parcas a respeito, fazendo referência à espécie apenas em dois textos: numa constituição de Diocleciano e Maximiano, ${ }^{2}$ in Dioclet. et Maxim., C. 7, 75, 6 (de 293 d.C.), e na passagem, atribuida a Paulo, que se encontra em 2 man., D. $42,1,51 \mathrm{pr}$.

Diz a constituição de Diocleciano:

Si actu sollemni praecedentem obligationem peremisti, perspicis adversus fraudatorem intra annum in quantum facere potest vel dolo malo fecit, quo minus possit, edicto perpetuo tantum actionem permitti.

[Se por ato solene extinguiste obrigação anterior, sabes perfeitamente

1. Ver, entre outros, Betti, Diritto Romano I, Padova, Cedam, 1935, p. 588; Girard, Manuel Élémentaire de Droit Romain, 8" ed., Paris, Arthur Rousseau, 1929, p. 1.113, nota 4; Garcia-Garrido, Derecho Privado Romano, 4" ed., Madrid, Dykinson, 1989, p. 246; e Monier, Manuel Élémentaire de
Droit Romain, v. 1, 6a ed., Paris, Domat Montchrestien, 1947, p. 174.

2. Embora diversos autores afirmem ser a data dessa constituição desconhecida, Levet, Le bénéfice de compétence, Paris, Recueil Sirey, 1927, p. 140, nota 14, a situa, oferecendo argumentos,
por volta do ano 293 d.C. 
que o edito perpétuo somente dentro de um ano admite ação contra o fraudador, pelo que puder fazer ou pelo que dolosamente tiver deixado de poder.]

São estas as palavras de Paul. 2 man., D. 42, 1, 51 pr.:

Si quis dolo fecerit, ut bona eius venirent, in solidum tenetur.

[Se alguém tiver agido com dolo para se venderem seus bens <em concurso>, responderá integralmente <perdendo o benefício de ser condenado pelo que podia pagar $>$.]

No processo formular, o réu, depois de condenado, tinha o prazo de trinta dias para cumprir espontaneamente a sentença. ${ }^{3}$ Caso isto não acontecesse, o autor podia mover contra ele a actio iudicati, ${ }^{4}$ procedimento executivo do novo sistema processual que veio substituir a manus iniectio das ações da lei. ${ }^{5}$

A actio iudicati, assim como o processo de cognição, constava de duas fases: uma perante o magistrado (in iure), e outra perante o iudex, o juiz particular que arbitrava o processo (apud iudicem).

O procedimento executivo costumava encerrar-se, ordinariamente, na fase in iure, com o reconhecimento da sentença por parte do devedor, se não tivesse motivos para impugná-la, e o cumprimento espontâneo da mesma.

3. Para maior aprofundamento a respeito da sua execução forçada vide Wenger, Compendio de Derecho Procesal Civil Romano, 2" ed. in Jörs - Kunkel, Derecho Privado Romano, trad. esp. da $2^{2}$ ed. alemã por L. Pietro Castro, Barcelona, Labor, 1937, pp. 533-5; Kaser, Derecho Privado Romano, trad. esp. da $5^{a}$ ed. alemã por José Santa Cruz Teịjeiro, 2" ed., Madrid, Reus, 1982, pp. 379-81; D'Ors, Derecho Privado Romano, 5" ed., Pamplona, Eunsa, 1983, pp. 160-8; e Moreira Alves, Direito Romano, v. I, 6" ed., Rio de Janeiro, Forense, 1987, pp. 280-3. O prazo era fixado pela Lei das XII Tábuas $(3,1)$.

4. De acordo com Wenger, Compendio de Derecho Procesal..., cit. (nota 3 supra), p. 533, o Direito Romano não-autorizava o credor a executar a sentença por conta própria, incumbência esta que cabia ao Poder Público. Além do iudicatus (réu condenado que não cumprira a sentença), também o confessus (devedor que reconhece in iure o direito do autor) e o indefensus (aquele que, citado, não comparecia para se defender ou o fazia inadequadamente) poderiam sofrer a actio iudicati. Cf. Kaser, Derecho Privado..., cit. (nota 3 supra), p. 380, e Wenger, Compendio de Derecho Procesal.., cit. (nota 3 supra), p. 535

5. No sistema das ações da lei. a manus iniectio conduzia em última análise à addictio da pessoa do devedor em favor do credor vencedor da lide. Esta situação podia se dar em decorrência de um iudicatum, de uma confessio in iure relativa a divida pecuniária ou em virtude de uma damnatio. $\mathrm{Cf}$. D'Ors, Derecho Privado..., cit. (nota 3 supra), p. 161. A propósito da sobrevivência da execução pessoal no Direito clássico, vide Poveda Velasco, Algumas considerações à respeito do beneficium competentiae in Revista da Faculdade de Direito da Universidade de São Paulo, v. 91 (96), p. 50, nota 4. 
Se, contudo, o réu negasse a existência da sentença ou alegasse nulidade da mesma, o pretor, após obrigá-lo a prestar garantias de que cumpriria a nova sentença correspondente, via de regra, ao dobro da primeira , nomeava um juiz popular e o processo avançava para a fase apud iudicem, na qual apurar-se-ia a verdade da alegação do réu. Esta fase se encerrava pela decisão do iudex, absolvendo o réu ou confirmando a primeira sentença e condenado-o in duplum.

Recalcitrando o réu em cumprir o iudicatum, o credor obtinha autorização do magistrado para realizar os ulteriores atos executivos. ${ }^{7}$

A execução coercitiva da sentença, iniciava-se mediante requerimento do credor (ou de um dos credores, no caso de ação movida por vários deles) dirigido ao pretor para que este o imitisse na posse dos bens do devedor. A imissão, a título provisório, visava evitar que o réu dilapidasse seus bens, prejudicando assim a execução (missio in bona rei servandae causa).

No Direito Romano clássico, a execução era em regra patrimonial, com um caráter de universalidade que a distinguia da nossa moderna execução real: não recaía sobre bens determinados, tantos quantos necessários para saldar a dívida, mas se estendia à totalidade do patrimônio do devedor. ${ }^{8}$ É a denominada execução concursual, à qual eram chamados todos os credores do réu. ${ }^{9}$

6. Lis infitiando crescit in duplum. Ver Gai. 4, 9; Inst. 4, 6, 26; Ulp. 15 ed., D. 5, 3, 20, 4; e Paul. $18 \mathrm{ed}$, D. 12, 2, $30 \mathrm{pr}$. Infitians era aquele que, sem razão, contestava a pretensão do autor, o qual sairia, mais tarde, vencedor. A litiscrescência é característica de todas as ações que substituíram a antiga manus iniectio, na qual o vindex, que intervinha em favor do réu, ficava obrigado ao dobro. É o caso da actio iudicati e, também, daquelas que se baseavam numa damnatio, quer decorrente de lei pública (como, por exemplo, a Lex Aquilia e outras do começo do séc. II a.C., como a Lei Publíbia de sponsu (actio depensi), a Lei Fúria de sponsu ou a Lei Fúria testamentária, e mesmo de algumas do começo da período clássico, como a Lei Márcia contra os usurários, do ano 104 a.C.), quer de lei privada (como a actio ex testamento e actio de modo agri). Não se devem confundir com as ações penais in duplum. Cf. D'Ors, Derecho Privado..., cit. (nota 3 supra), pp. 156-7.

7. Cf. Wenger, Compendio de Derecho Procesal..., cit. (nota 3 supra), pp. 534-5.

8. Para Kaser, Derecho Privado... cit. (nota 3 supra), p. 379, este é um vestígio da execução pessoal da qual procede. No Direito clássico introduziram-se aos poucos exceções ao princípio da venda total do patrimônio do devedor, no caso de execução contra pessoas de classe senatorial (clarae personae) e contra certas pessoas necessitadas de proteção. A venda de bens singulares talvez fosse, também, permitida por acordo dos credores. Cf. D'Ors, Derecho Privado..., cit. (nota 3 supra), p. 167. Na época da extraordinaria cognitio a execução concursual passa a ser exceção, sendo regra aquela que se realiza mediante o embargo de coisas determinadas do patrimônio do devedor (pignus in causa iudicati captum). Cf., nesse sentido, Wenger, Compendio de Derecho Procesal..., cit. (nota 3 supra), p. 535 .

9. Ver, a propósito, Solazzi, /l concorso dei creditori nel Diritlo Romano, 4 v., Napoli, Jovene, 1937-1943. 
Acolhendo mediante decretum o requerimento do credor, o magistrado autorizava-o a imitir-se na totalidade dos bens do devedor, nomeando-o administrador provisório dos mesmos. O administrador, chamado curator bonorum, devia divulgar editais tornando pública a imissão, a fim de permitir que outros credores do réu, conhecendo o fato, se habilitassem à execução, e também de permitir que amigos ou parentes do réu pagassem por ele o montante da condenação.

Decorridos trinta dias, ou quinze em se tratando da herança de devedor falecido, o magistrado mediante novo decretum, agora com caráter infamante, determinava a venda do patrimônio do devedor e a nomeação de um magister bonorum encarregado de efetuá-la. Esse processo recebia o nome de bonorum venditio, o qual, de acordo com Gaio, ${ }^{10}$ parece ter sido introduzido pelo pretor Públio Rutílio Rufo, em 118 a.C."

A venditio deveria ser realizada dez dias após a nomeação do magister bonorum, sendo os bens entregues ao licitante (designado com o nome de bonorum emptor $)^{12}$ que maior preço oferecesse por eles. ${ }^{13}$

O produto da venda era, finalmente, repassado ao credor (ou dividido entre os credores, se vários), ${ }^{14}$ subsistindo a obrigação do réu pelas dívidas nãosatisfeitas, caso a venda não tivesse bastado para pagá-las integralmente.

\section{Cf. Gai 4,35 .}

11. Alguns autores, como D'Ors, Derecho Privado... cit. (nota 3 supra), p. 161, sustentam que a execução patrimonial é muito anterior ao pretor Públio Rutílio. Cf., também, Moreira Alves, Direito Romano..., cit. (nota 3 supra), p. 281 e nota 454.

12. O bonorum emptor, por analogia com o herdeiro pretoriano (bonorum possessor), era considerado sucessor do devedor concursado. Por esta razão, eram-lhe concedidas, a favor e contra, as ações do devedor e contra ele, mediante a formula ficticia, fingindo que o bonorum emptor herdava do devedor. Cf., nesse sentido, Kaser, Derecho Privado... cit. (nota 3 supra), p. 381, e D'Ors, Derecho Privado..., cit. (nota 3 supra), p. 166.

13. A rigor, a alienação não se realizava por preço fixo, mas se concretizava em favor daquele que se dispusesse a pagar a mais alta percentagem dos créditos dos exeqüentes. De acordo com Kaser, Derecho Privado..., cit. (nota 3 supra), pp. 380-1, a alienação mediante leilão era uma forma grata aos romanos. Não-somente a adjudicação de obras públicas, mas também o arrendamento de contribuições aos publicanos (publicani) observava este procedimento. D'Ors, Derecho Privado..., cit. (nota 3 supra), p. 165, faz notar que sendo a insolvência compativel com a existência de bens, mesmo que não imediatamente liqüidáveis, costumava-se especular com bastante lucro na compra de patrimônios concursados, que eram liqüidados mais tarde, sem pressa, em boas condições.

14. Da massa concursual era necessário separar os bens alheios ao devedor. Além disso, certos créditos eram privilegiados e deviam ser satisfeitos em primeiro lugar pelo bonorum emptor. É o caso dos que gozavam de garantia real; daqueles provenientes de gastos com o enterro, se fosse o caso; o da mulher pela restituição do dote; os créditos do Fisco e das cidades (res publicae), etc. Cf. D'Ors, Derecho Privado..., cit. (nota 3 supra), pp. 164-5. 
Segundo a opinião dominante, os credores ex ante gesto, ou seja, aqueles anteriores à venda dos bens, podiam processar o devedor submetido à bonorum venditio, a fim de obter dele plena satisfação de seus direitos. Em virtude, porém, de determinação edital ${ }^{15}$ o insolvente, dentro do ano contado a partir da venditio, seria condenado apenas in id quod debitor facere potest. ${ }^{16}$ Se o devedor, contudo, tivesse dolosamente provocado a própria insolvência, seria, de acordo com Paul. 2 man., D. 42, 1, 51 pr., condenado in solidum. ${ }^{17}$

Qual a vantagem, em termos práticos, do beneficium competentiae concedido ao falido? Evitar a infâmia não seria, pois infamis ele já era, desde o início do processo executório, em conseqüência do decretum do pretor que autorizara a bonorum venditio. A maior vantagem consistia, então, em defendê-lo da voracidade dos credores, evitando que ele ficasse sujeito a novas venditiones toda vez que conseguisse amealhar novo patrimônio. Adquirindo novos bens, o iudicatus poderia ser novamente demandado, porém, dentro do prazo anual contado a partir da bonorum venditio, o seria apenas no limite de seu patrimônio.

Esta regra, contudo, não se aplicava ao credor que tivesse tido a iniciativa da actio iudicati. Como bem observa Marrone, ${ }^{18}$ o credor-autor do processo de cognição e da ulterior ação executiva não podia repropor a ação porque, relativamente à eadem res, ficava-Ihe preclusa a reiteração da mesma. Se o réu viesse a adquirir novos bens, caberia a este credor tão-somente requerer ao magistrado a continuação da execução, pois seu "título" seu direito à execução não se tinha exaurido.

Os credores ex ante gesto dos quais se diz que deveriam agir contra o

15. A referência ao edito aparece em Dioclet. el Maxim., C. 7, 75, 6 (de 293 d.C.). Contudo, alguns autores como Kaser, Das römische Zivilprozessrecht, München, C. H. Beck, 1966, p. 310, nota 19 e D'Ors, Derecho Pivado..., cit. (nota 3 supra), p. 167, nota 2, põem em dívida essa pretensa base edital. Solazzi, L'estinzione della obbligazione, Napoli, Jovene, 1931, p. 209, nota 3, questiona a autenticidade dessa passagem do Código. No mesmo sentido, também, Kaser, Derecho Privado..., cit. (nota 3 supra), 381. Contrariamente às objeções de Solazzi, ver Guarino, La condanna nei limiti del possibile, 2" ed., Napoli, Jovene, pp. 35-6.

16. A doutrina diverge sobre o termo inicial desse prazo. Para Guarino, La condanna .., cit. (nota 15 supra), p. 35, primeiramente o beneficium teve aplicação intra annum, ou seja, dentro do ano de mandato do pretor que tivesse deferido a venditio. Mais tarde, o prazo teria se tornado anual, contado a partir da data da venda dos bens.

17. Cf., nesse sentido, Monier, Manuel Élémentaire..., cit. (nota 1 supra), v. 1, p. 174 e D'Ors, Derecho Privado..., cit. (nota 3 supra), p. 167 e nota 2.

18. Cf. Marrone, Note di Diritto Romano sul c.d. "beneficium competentiae" in Aupa (Annali del Seminario Giuridico dell'Università di Palermo), 36 (1976), pp. 15 e ss. 
falido nos limites do in id quod facere potest seriam, em primeiro lugar, aqueles que tendo já obtido a condenação do devedor em ação de cognição por eles proposta, tivessem participado do procedimento concursual requerido por outro credor, sem entretanto haverem exercido a actio iudicati. Ao lado destes figurariam também aqueles que, sem terem movido a ação de cognição nem a executória, teriam-se beneficiado do concursus, assim como o credor que tivesse acionado o procedimento concursual após a indefensio, a absentia ou a latitatio do devedor, dispensando a actio iudicati e, eventualmente, a ação de cognição. Como é lógico, eram, finalmente, contemplados todos os outros eventuais credores ex ante gesto que não tivessem participado do procedimento concursual ou mesmo nem tivessem chegado a propor a actio iudicati. Nenhum deles possuía "título" para pedir a reabertura pura e simples da execução; por isso, pelos débitos remanescentes, deveriam propor contra o falido a ação de cognição, ou se já o tivessem feito, a actio iudicati. Em todos esses casos inexistiria o perigo de julgamento de eadem re.

Discute-se sobre se os ulteriores desdobramentos do processo executório incluiriam a possibilidade do credor promover a execução pessoal do devedor. Referimo-nos, obviamente, ao credor-autor da actio iudicati que provocou o procedimento concursual pois, em relação aos demais credores ex ante gesto, gozava o falido do beneficium competentiae, o qual obstava a execução sobre a sua pessoa.

A maioria dos autores ${ }^{19}$ não toma posição a este respeito. Marrone, ${ }^{20}$ embora reconhecendo que as fontes silenciam a respeito, entende que, em harmonia e por coerência com a cláusula edital que concedia ao falido o beneficium competentiae, o magistrado negaria ao autor da actio iudicati, dentro do prazo de um ano e pelos débitos restantes ex ante gesto, a possibilidade de execução pessoal. ${ }^{21}$

A hipótese parece razoável. Nesse caso, a vantagem deste credor sobre os outros consistiria na maior facilidade para satisfazer seu crédito restante, pois,

19. Assim, Guarino, La condanna... cit. (nota 15 supra), pp. 32-38; Solazzi, L'estinzione..., cit. (nota 15 supra), p. 209; e Levet, Le bénéfice.... cit. (nota 2 supra), pp. 138-41. Guarino, La condanna..., cit. (nota 15 supra), p. 37, refere-se à possibilidade de addictio do devedor, como decorrência, porém, da interposição da antiga legis actio per manus iniectionem a qual, na sua opinião, ainda podia ser proposta em pleno séc. I a.C., pois não fora atingida pela reforma da Lex Iulia iudiciorum privatorum.

20. Cf. Note di Diritto Romano.... cit. (nota 18 supra), pp. 17-8.

21. Segundo Marrone, Note di Diritto Romano... cit. (nota 18 supra), p. 17, é bem provável que isto fosse expressamente declarado no edito. 
para tanto, bastar-lhe-ia pedir ao pretor o prosseguimento da execução mediante nova bonorum venditio, enquanto os outros deveriam propor a ação oportuna. ${ }^{22}$

Contudo, essa vantagem de nada valeria se o devedor continuasse sem patrimônio. Por esta razão, e dado que a execução pessoal, como já referido, perdurou durante todo o período clássico, não nos repugnaria pensar na possibilidade de sua implementação. ${ }^{23}$ Neste caso, executado o patrimônio do falido, o autor da actio iudicati poderia satisfazer seu crédito restante, utilizando os trabalhos do devedor. Aos demais credores ex ante gesto restaria a expectativa de que, libertado dos trabalhos forçados, o falido viesse a amealhar novos bens para, então sim, processá-lo, mas apenas in id quod facere potest até o fim do prazo anual.

O motivo da concessão do benefício parece ter sido certa compaixão perante a lamentável situação do falido, antepondo-se, na expressão de Guarino, ${ }^{24}$ algum entrave à vileza dos credores ex ante gesto que inescrupulosamente investiam contra aquele, sem um mínimo de humana compreensão.

\section{O bonis cedens}

A difícil situação do devedor insolvente, ameaçado com a perspectiva de sofrer uma bonorum venditio coercitiva e as conseqüências que ela acarretava, experimentou sensível atenuação desde o aparecimento da cessio bonorum.

Introduzida, parece, por uma discutida Lex Iulia de bonis cedendis, ${ }^{25}$

22. De acordo com Mod. 2 pand., D. 42, 3, 7, nova venditio seria autorizada somente no caso do falido ter adquirido uma soma de bens tal que, a juizo do pretor, justificasse a medida.

23. De resto, o próprio Marrone, Note di Diritto Romano..., cit. (nota 18 supra), p. 17, nota 5 , reconhece que o devedor condenado in id quod facere potest não escaparia da execução pessoal caso não pagasse 0 valor da condenação.

24. Cf. La condanna..., cit. (nota 15 supra), p. 37.

25. Gai. 3, 78 diz que a bonorum venditio praticava-se, também em relação aos bens daqueles qui ex lege lulia bonis cedunt. Da mesma forma, um rescripto de Diocleciano e Maximiano, de 294 d.C. (Dioclet. et Maxim., C. 7, 71, 4) remete a condemnatio limitada do bonis cedens a uma Lex Iulia de bonis cedendis. Discute-se se a paternidade dessa lei deve ser atribuida a César ou a Augusto, os dois Iulios por antonomásia. A communis opinio inclina-se por Augusto, supondo até que a referida lei fosse, na verdade, apenas uma parte da Lex Lulia iudiciorum privatorum, do ano 17 a.C., ou da Lex Iulia iudiciorum (seja privatorum, seja publicorum), do mesmo ano, de conteúdo mais amplo. Cf., nesse sentido, Guarino, La condanna..., cit. (nota 15 supra), p. 42; Kaser, Derecho Privado..., cit. (nota 3 supra), p. 381; Marrone, Note di Diritto Romano..., cit. (nota 18 supra), p. 6; e Solazzi, Il concorso dei creditori..., cit. (nota 9 supra), v. 4, pp. 133 e ss. Contudo, há quem entenda, como Giuffrè, La c. d. "Lex Iulia de bonis cedendis" in Labeo, 18 (1972), pp. 173 e ss., que o instituto é da 
ela permitia ao devedor insolvente evitar o efeito infamante da execução patrimonial forçada e escapar de uma possível execução pessoal, desde que entregasse seus bens aos credores.

A cessio bonorum realizava-se mediante solicitação expressa $\cdot$ do devedor insolvente, que o pretor acolhia sob certas condições. Se deferida, o magistrado autorizava um procedimento análogo ao da missio in bona e ao da bonorum venditio: nomeação de um curator bonorum, venda dos bens em leilão, etc. $^{26}$ A diferença maior estava em que o decretum do magistrado determinando a venditio não acarretava infâmia.

Por se tratar de instituto bastante favorável ao devedor, Guarino ${ }^{27}$ entende que, ao deferir o pedido de cessio, o magistrado devia levar em conta algumas circunstâncias, tais como o fato do requerente não ser infamis em virtude de bonorum venditio anterior, ou o de que a cessão dos bens garantisse uma razoável satisfação aos credores.

Ulpiano, 26 ed., D. 42, 3, 8 afirma:

Qui cedit bonis, antequam débitum adgnoscat, condemnetur vel in ius confiteatur, audiri non debet.

[Aquele que deseja fazer cessão de seus bens não deve ser atendido enquanto não reconheça sua dívida, não seja condenado ou não confesse perante o magistrado].

O texto é entendido, não porém sem controvérsias, no sentido de que o devedor somente fosse admitido à cessio bonorum após ter reconhecido o próprio débito ou depois da condenação. ${ }^{28}$

Semelhante entendimento não permite, contudo, conciliar o texto citado com os ensinamentos de Ulp. 58 ed., D. 42, 3, 3 e Paul. 56 ed., D. 42, 3, 5, os quais ofereciam ao cedens a possibilidade de reconsiderar sua decisão de entregar os bens e se defendere. ${ }^{29}$ Como poderia ele se defendere após a condemnatio ou a

época de César, e de criação não legislativa mas pretoriana. Cf., nesse sentido também, D'Ors, Derecho Privado..., cit. (nota 3 supra), p. 164.

26. Cf., supra, parte 1 do presente artigo.

27. Cf. La condanna..., cit. (nota 15 supra), p. 39.

28. Cf. Marrone, Note di Diritlo Romano..., cit. (nota 18 supra), p. 21.

29. Ullp. $58 \mathrm{ed}$, D. 42, 3, 3: Is, qui bonis cessit, ante rerum venditionem utique bonis suis non caret: quare si paratus fuerit se defendere, bona eius non veneunt [Aquele que fez a cessão de seus 
confessio?

Após longa exegese dos textos citados, Marrone ${ }^{30}$ conclui que o ensinamento de Ulpiano, $26 \mathrm{ed}$, D. 42, 3, 8 não limitava a concessão da cessio ao confessus ou ao iudicatus: verificadas as circunstâncias que tornavam possível sua admissibilidade, qualquer devedor, antes de ser chamado a juízo por algum dos seus credores, era admitido à cessio. Nesse sentido, qualquer devedor que, sem própria culpa, se visse insolvente, poderia pretender a entrega voluntária de seus bens. ${ }^{31}$

Não seria, porém, admitido à cessio bonorum o devedor que, chamado a juízo, recusasse se defendere, salvo se, em tal caso, o credor-autor o permitisse. ${ }^{32} \mathrm{E}$ isto porque a indefensio ocasionava sanções pretórias, como a imediata imissão na posse dos bens do indefensus, a execução patrimonial forçada, com nota infamante, e a eventual execução pessoal, ${ }^{33} \cdot$ tornando a cessio sem alcance.

Entende Marrone $^{34}$ que, provavelmente, pudesse ser também admitido

à cessio bonorum o devedor que fizesse a confessio in iure no âmbito da actio

bens <aos credores> não se vê privado de seu patrimônio até a venda dos mesmos, razão pela qual, estando disposto a se defender, não procede a venda de seus bens].

Paul. 56 ed., D. 42, 3, 5: Quem paenitet bonis cessisse, potest defendendo se consequi, ne bona eius veneant [Quem se arrepende de ter cedido os bens, pode conseguir, defendendo-se em juízo, que não se vendam].

30. Cf. Note di Diritto Romano..., cit. (nota 18 supra), pp. 22-31.

31. Cf. Kaser, Derecho Privado..., cit. (nota 3 supra), p. 381. Ver, também, D'Ors, Derecho Privado..., cit. (nota 3 supra), p. 164.

32. Marrone, Note di Diritto Romano..., cit. (nota 18 supra), pp. 24 e ss., examinando o passo de D. 42, 3, 8 no contexto da obra de Ulpiano (livro 26 ad edictum, dedicado ao edito «si certum petetur»), conclui que o jurisconsulto estava se referindo ao indefensus e analisando as consequuências da indefensio em face da obrigação de efetuar o juramento necessário (cf., a respeito, Wenger, Compendio de Derecho Procesal..., cit. (nota 3 supra), pp. 528, 531 e 539). No contexto originário, e em conexão com o tema do juramento necessário contemplado na cláusula edital «si certum petetur», Llpiano devia se perguntar se a sançào pretória contra o réu que se recusasse a solvere ou a iurare, poderia ser evitada pelo próprio réu mediante a cessio bonorum. Para Marrone, a resposta de Ulpiano seria negativa, pois a recusa pura e simples de jurar sem, por outro lado, efetuar a solutio, equivalia à indefensio, e o indefensus, para Ulpiano, não podia bonis cedere. Por outro lado, o réu não mais seria considerado indefensus se fizesse a confessio in iure do próprio débito, sendo admissivel depois dela a bonorum cessio. O réu, igualmente, não seria mais considerado indefensus se aceitasse se defendere, $\mathrm{e}$ também neste caso, após a condemnatio, a cessio seria admissivel. Para Marrone, é nesse sentido que Ulpiano, querendo exprimir a idéia de que o indefensus não podia bonis cedere validamente, teria escrito o que hoje se lê em Ulp. 26 ed., D. 42, 3, 8: Qui cedit bonis, antequam debitum adgnoscat, condemnetur vel in ius confiteatur, audiri non debet. Mais tarde essa referência ao indefensus teria sido suprimida quando do momento da adaptação e inclusão do texto in D. 42, 3 .

33. Cf., supra, parte 1 , nota 4.

34. Cf. Note di Diritto Romano..., cit. (nota 18 supra), p. 30. 
iudicati, mas não aquele condenado na ação executiva, pois à cessio eram apenas admitidos devedores, genericamente falando, dignos de consideração, o que não era o caso daquele que teimosamente tivesse negado o próprio débito ao ponto de opor infundada resistência até na actio iudicati.

Neste contexto, então, de maior acesso à cessio bonorum compreendese que, como afirmam D. 42, 3, 3 e 5 já-citados, um devedor, depois de efetuar a cessão de seus bens, pudesse arrepender-se, revogar a cessio e se defendere. ${ }^{35}$

Deferido, pelo magistrado, o pedido do devedor insolvente, os credores eram obrigados a aceitar a cessio bonorum. ${ }^{36}$ Contudo, poderiam exigir, posteriormente, o remanescente da dívida caso a venda dos bens do cessor nãobastasse para satisfazer seus créditos.

A bonorum cessio, além de excluir a nota infamante que normalmente acompanhava a venda forçada dos bens do devedor, concedia ao bonis cedens, por tempo indeterminado, o beneficium competentiae em relação aos credores ex ante gesto, quando fosse acionado para o pagamento das dívidas restantes. É o que afirma Ulpiano, 59 ed., D. 42, 3, 4 pr.:

Is qui bonis cessit, si quid postea adquisierit, in quantum facere potest convenitur.

[Aquele que fez cessão de seus bens, se tiver depois adquirido outros bens, responde < pelas dívidas anteriores tão-somente> até onde possa pagar]. ${ }^{37}$

$\mathrm{Na}$ opinião de Marrone é pacífico na doutrina, e além disso lógico e

35. De acordo com Marrone, Note di Diritto Romano..., cit. (nota 18 supra), pp. 30-1, tal possibilidade de se defender apresentar-se-ia, ao réu confessus na ação declaratória, por ocasião da posterior ação executiva. Para os demais devedores-cedentes, essa possibilidade se apresentaria no âmbito da ação declaratória. Parece-nos, contudo, que a possibilidade de revogar a cessio e se defendere no âmbito da actio indicati deveria existir, também, para o réu que, após a condemnatio da ação declaratória, tivesse requerido a cessão dos bens. A esta condemnatio é que estaria se referindo Ulp. 26 ed., D. 42, 3, 8. Ao condenado na ação executiva não seria, pelo contrário, deferida a cessio, conforme opinião de Marrone referida supra.

\section{Cf. D'Ors, Derecho Privado.... cit. (nota 3 supra), p. 164.}

37. Do mesmo teor é Inst. 4, 6, 40: Eum quoque, qui creditoribus suis bonis cessit, si postea aliquid adquisierit, quod idoneum emolumentum habeat, ex integro in id quod facere potest creditores cum eo experiuntur: inhumanum enim erat spoliatum fortunis suis in solidum damnari [Também o que fez cessão de seus bens aos credores, adquirindo depois o que o torne solvente, eles o acionam para fazê-lo pagar tudo quanto puder; pois desumano seria fosse o desfalcado na sua fortuna condenado no total]. Ver também, nesse sentido, Litewski, Das "beneficium competentiae» im römischen Recht in Studi Volterra, 4 (1971), p. 559, para quem a expressão "quod idoneum emolumentum habeat" é interpolada. 
equitativo, que o beneficium competentiae a favor do bonis cedens se limitasse aos débitos residuais ex ante gesto, o que se desprende, também, de Inst. 4, 6, 40: o bonis cedens, sibi imputet os eventuais débitos contraídos após a cessio, não merecendo, por isso, nenhuma consideração. ${ }^{38}$

Além disso, em relação a qualquer credor, a cessio impedia nova bonorum venditio, enquanto o patrimônio do cedente não tivesse alcançado um modicum aliquid, uma consistência mínima, a juízo do pretor. ${ }^{39}$

De acordo com Ulpiano, 64 ed., D. 42, 3, 6, esse modicum aliquid deveria ser estimado não pela qualidade mas pela quantidade dos bens adquiridos. ${ }^{40}$

O cedens que ainda não tivesse adquirido bens suficientes para justificar nova venditio poderia defender-se contra todos os credores mediante a exceptio nisi bonis cesserit. Esta exceção perderia eficácia em caso contrário. A partir desse momento o beneficium competentiae aplicava-se: os credores ex ante gesto recobravam o direito de agir contra o cedens, mas sua condenação seria apenas in id quod facere potest. ${ }^{41}$ Para evitar que a exceptio nisi bonis cesserit malograsse suas pretensões, o credor, na opinião de Guarino, ${ }^{42}$ devia limitar seu pedido através de uma praescriptio do tipo «ea res agatur in quantum reus facere potest».

Entendido desta forma, o benefício apresenta-se, para Levet, ${ }^{43}$ como complemento indispensável da cessio bonorum, dando plena eficácia à reforma pretendida por Augusto ao promulgar a Lex Iulia de bonis cedendis.

38. Cf. Note di Diritto Romano..., cit. (nota 18 supra), p. 19. Ver nesse sentido também Levet, Le bénéfice..., cit. (nota 2 supra), p. 137 e nota 6.

39. Mod. 2 pand., D. 42, 3, 7: Si debitoris bona venierint, postulantibus creditoribus permittitur rursum eiusdem debitoris bona distrahi, donec suum consequantur, si tales tamen facultates adquisitae sunt debitori, quibus praetor moveri possit [Vendidos os bens de um devedor, permite-se que, a pedido dos credores, seu patrimônio seja novamente alienado, até eles conseguirem aquilo que lhes é devido, caso o devedor tenha adquirido tantos bens que, a juízo do pretor, justifiquem a medida].

40. Ulp. 64 ed., D. 42, 3, 6: Qui bonis suis cessit, si modicum aliquid post bona sua vendita adquisivit, iterum bona eius non veneunt, unde ergo modum hunc aestimabimus, utrum ex quantitate eius quod adquisitum est an vero ex qualitate? et putem ex quantitate id aestimandum esse eius quod quaesiit... [Se quem cedeu seus bens adquiriu depois alguma coisa a mais, a venda não se repete enquanto esse novo patrimônio não atingir um certo valor. Como estimaremos, pois, essa medida? Pela quantidade do adquirido ou pela sua qualidade? E penso que se deve estimar o adquirido pela quantidade...].

41. Cf. Levet, Le bénéfice..., cil. (nota 2 supra), p. 137.

42. Cf. La condanna..., cit. (nota 15 supra), p. 38.

43. Cf. Le bénéfice..., cit. (nota 2 supra), pp. 135 e 137. 
O beneficium competentiae do bonis cedens, atingia todos os credores ex ante gesto? Tal é a questão que Marrone volta a discutir a propósito dos aspectos relativos à cessio bonorum, como já fizera no estudo da condenação limitada em favor do falido. ${ }^{44}$ Pelas mesmas razões apresentadas neste último caso, Marrone considera que o benefício valia contra todos os credores ex ante gesto, com exceção daquele credor perante o qual, antes da cessio, o devedor tivesse feito, na actio iudicati, confessio do próprio débito: a este era preclusa qualquer actio, fosse de cognição ou executiva pois, de eadem rem, o credor não podia voltar a agir contra o mesmo devedor, nem mesmo limitando a demanda ao id quod reus facere potest. ${ }^{45}$

Para exigir os créditos restantes ex ante gesto e satisfeitos os requisitos sobretudo, a existência daquele modicum aliquid, este credor poderia requerer diretamente a reabertura da execução. Para tanto, possuia ele um "título", que não tinha se esgotado com a execução anterior.

$\mathrm{Na}$ falta de título direto para a execução, os demais credores ex ante gesto deviam propor contra o bonis cedens, conforme o caso, ação declaratória ou executiva, e tanto num caso quanto noutro, a condenação não poderia ultrapassar o limite do id quod debitor facere potest. ${ }^{46}$

De acordo com Guarino, a ratio da concessão do benefício em favor do cedens era idêntica à do benefício, mais restrito, concedido ao falido, qual fosse mitigar a intemperança perversa dos credores ex ante gesto ${ }^{47}$

Em nossa opinião, o benefício se justifica, também, enquanto meio de recompensar, com tratamento mais favorável, aquele devedor insolvente que, se antecipando em oferecer seus bens aos credores, manifestava a louvável disposição de lhes satisfazer os créditos.

Finalmente, trata-se, sem dúvida, de expediente destinado a possibilitar a reabilitação econômica do devedor. ${ }^{48}$

Resta abordar uma última questão: se a Lex Iulia de bonis cedendis, introduzindo a cessio bonorum, ofereceu a todo e qualquer devedor a possibilidade

44. Cf. Note di Diritto Romano..., cit. (nota 18 supra), pp. 20 e ss. Ver, também, parte 2, supra.

45. Marrone considera que somente ele, entre os doutrinadores, tem proposto esta questão. Cf. Note di Diritto Romano..., cit. (nota 18 supra), p. 21 , nota 5.

46. Cf. Note di Diritto Romano..., cit. (nota 18 supra), pp. 31-2.

47. Cf. La condanna..., cit. (nota 15 supra), p. 43.

48. Cf., nesse sentido, Kaser, Derecho Privado... cit. (nota 3 supra), p. 381 
de furtar-se à execução patrimonial forçada, agravada pela correspondente infamia, $\mathrm{e}$ a uma eventual execução pessoal, desde que oferecesse seus bens aos credores, como explicar a sobrevivência do beneficium competentiae e, mais ainda, sua ampliação a novos casos ao longo dos séculos? ${ }^{49}$

Os autores oferecem diversas explicações possíveis. Uma delas seria que, no caso do beneficium competentiae, ao calcular o id quod facere potest, ficaria reservado um aliquid sufficiens ne egeat, um mínimo necessário à sobrevivência do devedor, enquanto na cessio bonorum nada restaria ao cedens.

Outra possível vantagem seria esta: no beneficium, o passivo patrimonial, ou seja, as outras dívidas do beneficiário (aes alienum) seriam deduzidas no momento do cômputo do id quod reus facere potest, mas não no caso da cessio.

Tem-se, ainda, afirmado que enquanto o devedor somente poderia ceder seus bens quando sua insolvência fosse decorrente de caso fortuito ou força maior (sine vitio), o beneficium competentiae somente seria excluído se ele tivesse agido com dolo.

A condenação limitada, em fim, liberaria o devedor da obrigação de pagar as dívidas remanescentes, enquanto é certo que o bonis cedens continuaria devendo aquela parcela de débitos não-satisfeita. ${ }^{50}$

Observa Marrone que os autores procuram, geralmente, encontrar a explicação da sobrevivência do beneficium competentiae baseando-se em razões que decorrem do confronto deste com a cessio bonorum. Sem negar algumas dessas possiveis vantagens relativas decorrentes da comparação entre ambos, Marrone faz notar, ${ }^{51}$ muito acertadamente em nosso entender, que é possível justificar a subsistência e a abrangência maior da condenação limitada se lembrarmos que o devedor insolvente que gozasse do benefício, tendo a possibilidade de ceder seus bens, poderia, no entanto, ter interesse em fazer valer o beneficium competentiae.

49. Cf., nesse sentido, Zanzucchi, Sul c. d. "beneficium competentiae» in BIDR (Bulletino dell'Istituto di Diritto Romano «Vittorio Scialoja»), 1918, 29, pp. 70 e ss.; Solazzi, L'estinzione..., cit. (nota 15 supra), pp. 194 e ss; Levet, Le bénéfice..., cit. (nota 2 supra), pp. 183 e ss.; Marrone, Note di Diritto Romano..., cit. (nota 18 supra), pp. 7 e ss.; e Litewski, Das «beneficium competentiae».., cit. (nota 37 supra), pp. 499 e ss.

50. Ver, ainda, outras possiveis vantagens do beneficium competentiae in Marrone, Note di Diritto Romano..., cit. (nota 18 supra), p. 8, nota 10.

51. Cf. Note di Diritto Romano..., cit. (nota 18 supra), pp. 9 e ss., nas quais expð̃e, também, argumentos contrários aos apresentados no texto. 
Tal seria o caso do devedor que, desconhecendo sua exata situação patrimonial, não soubesse se seus bens bastariam ou-não para cobrir determinada dívida.

Poderia acontecer que seu patrimônio fosse inferior aos débitos e, nesse caso, o efeito prático da cessio e do beneficium seria provavelmente o mesmo, pois ambos privá-lo-iam de seus bens. ${ }^{52}$ Mas, poderia também suceder o contrário, e então o benefício evitaria que o devedor se visse privado de todos os seus bens, o que aconteceria caso se realizasse a cessio.

Ocorre-nos outra razão plausível em virtude da qual o devedor poderia preferir valer-se do benefício em vez de fazer a entrega de todos os seus bens, e é esta: se resolvesse requerer a cessio bonorum, ele, desde o momento desta, ficava privado de seu patrimônio, enquanto que se preferisse socorrer-se do benefício, permaneceria com os bens até o encerramento do processo pela condemnatio limitada, o que representava, sem dúvida, uma vantagem. Mas, mesmo então, poderia negar-se a pagar a dívida, levando a discussão para a actio iudicati, finda a qual inexoravelmente perderia a parte do patrimônio correspondente à condenação. Porém, em qualquer caso, o devedor teria conservado a posse dos bens, podendo negociar com eles e até, quem sabe, aumentar seu patrimônio, o que nos parece vantagem considerável.

3. Filhos emancipados, deserdados e que exerceram o ius abstinendi

De origem edital é também o beneficium competentiae concedido aos filhos emancipati, exheredati e abstenti, executados por dívidas contraídas enquanto se achavam in potestate. ${ }^{53}$

É o que afirma Ulpiano, 29 ed., D. 14, 5, 2 pr.:

Ait praetor: «In eum, qui emancipatus aut exheredatus erit quive abstinuit se hereditate eius cuius in potestate cum moritur fuerit, eius rei nomine, quae

52. Em rigor, mesmo neste caso, o beneficium teria pelo menos uma vantagem com relação à cessio: o devedor que resolvesse invocar o beneficium e enfrentar a ação do credor, permaneceria na posse dos bens enquanto o processo não chegasse ao fim. O cedens, diferentemente, ficaria desde logo despojado de seu patrimônio.

53. Diversos autores, assim Levet, Le bénéfice..., cit. (nota 2 supra), p. 64, e Guarino, La condanna..., cit. (nota 15 supra), p. 46, situam a introdução desse beneficio nos começos do lmpério, fim do séc. I a.C. ou comę̧o do séc. I d.C. 
cum eo contracta erit, cum is in potestate esset, sive sua voluntate sive iussu eius in cuius potestate erit contraxerit, sive in peculium ipsius sive in patrimonium eius cuius in potestate fuerit ea res redacta fuerit, actionem causa cognita dabo in quod facere potest».

[Diz o pretor: «Darei ação, com conhecimento de causa, no limite do que puder pagar, contra aquele que tiver sido emancipado, ou deserdado, ou que se tiver abstido da herança do pai ou dono em cuja potestade estava ao tempo de sua morte, por aquilo que tiver sido contratado com o que estava submetido à potestade enquanto nela se encontrava, tanto se tiver contratado com seu consentimento ou autorização, quanto se a coisa tiver revertido no pecúlio do mesmo ou no patrimônio do pai ou dono sob cuja potestade se encontrava»].

A concessão do benefício, nesses três casos de filhos citados no edito, parece plenamente justificada e obedece a um critério de justiça.

Com efeito, não sendo sujeitos perante o ius privatum, os filii familias não possuíam patrimônio próprio, sendo certo que tudo quanto adquirissem revertia em proveito do pater.

Por outro lado, sendo sujeitos perante o ius publicum, era normal que pessoas as mais diversas com eles negociassem, com ou sem autorização paterna. Por vezes, e esta prática foi se tornando cada vez mais comum a partir do fim do séc. II a.C., o filius assumia dívidas na expectativa, tanto sua quanto dos credores, de poder pagá-las ao se tornar sui iuris.

De acordo com Levet, houve mudança no tocante ao conceito de obrigação na passagem do Direito antigo para o clássico. Naquele, o filius familias não podia nem se obrigar nem sofrer execução pessoal. Mais tarde, no Direito clássico, surge a noção abstrata de obrigação, por ela se comprometendo não mais o corpo do devedor, e sim sua fides, sua honra, seu nome, pelo que a obrigação tornase suscetível de ser assumida por toda criatura provida de razão. Em conseqüência disto, a jurisprudência de fins da República e começos do Império passa a reconhecer aos filhos a capacidade de se obrigarem por contrato. ${ }^{54}$

Essa capacidade nada mais era do que a capacidade de agir (ou

54. Cf. Le bénéfice..., cit. (nota 2 supra), pp. 61 e ss. Diversos textos, como Gaio, 3 ed. prov., D. 44, 7, 39, comprovam essa capacidade. Cf., também, Monier, Manuel Élémentaire..., cit. (nota 1 supra), v. 2, p. 83; Jörs \& Kunkel, Derecho Privado... cit. (nota 3 supra), p. 376; e Girard, Manuel Élémentaire.... cit. (nota 1 supra), p. 495. 
negocial), reconhecida àqueles que se encontravam sob a patria potestas. Os negócios jurídicos realizados por essas pessoas eram válidos mas, não possuindo elas a capacidade de serem titulares de direitos (capacidade de direito), tudo quanto adquirissem passava a integrar, automaticamente, o patrimônio do pater, do qual os juridicamente incapazes eram meros agentes.

Com as dívidas ocorria algo diverso. De acordo com o ius civile, o pater familias não respondia, a princípio, pelas dívidas contratuais das pessoas sob sua potestas, ficando obrigado apenas aquele que as contraisse. Diferentemente do escravo que assumia apenas uma obrigação natural, o filius familias obrigava-se civilmente, podendo por conseguinte ser demandado e condenado. ${ }^{55}$

A execução da sentença em sua pessoa esbarrava, contudo, na potestas do pai, de cujo poder o filho não podia ser subtraído; a execução patrimonial, por outro lado, tropeçava na incapacidade patrimonial do devedor, excetuando-se o caso daqueles que, a exemplo dos que gozavam do peculium castrense, possuíssem cabedal próprio. ${ }^{56}$

Diferente era a situação se a dívida do filho ou do escravo decorresse de delito. Provado o delito cometido por um filho in potestate ou por um escravo seu, o pater familias seria condenado na pena correspondente, da qual só se livraria transferindo ao demandante a propriedade do escravo ou deixando-lhe o filho in mancipio, entrega esta que recebia o nome de noxae deditio. Mais tarde, no Direito pós-clássico, o regime noxal deixou de se aplicar aos filhos por parecer desumano. ${ }^{57}$

Alcançada a esperada independência do pátrio poder, poderia acontecer que o devedor fosse efetivamente solvente, para alegria de seus credores ou, pelo contrário, se achasse na insolvência, restando nesse caso aos credores a execução patrimonial forçada seguida por eventual execução in personam.

Parece, contudo, haver certa injustiça no fato de se submeter à execução comum um filius familias que, incapaz de ter patrimônio próprio, adquiria

55. Cf., entre outros textos, Gai. 3 ed. prov., D. 44, 7, 39. Ver, a esse respeito, Talamanca, Istituzioni di Diritto Romano, Milano, Giuffrè, 1990, p. 130. De acordo com Levet, Le bénéfice..., cit. (nota 2 supra), p. 63, isto se devia ao fato do filius familias ter um patrimônio incluído no do pai, que receberia ao se tornar sui inris.

56. Cf., nesse sentido, Jörs \& Kunkel, Derecho Privado..., cit. (nota 3 supra), p. 376.

57. Mesmo no Direito clássico, a noxae deditio aplicava-se em certos casos apenas aos escravos, como sucedia com a actio de effusis vel deiectis. Cf. Gai. 3 res cott., D. 44, 7, 5, 5 e Inst. 4, 5, 2). Ver, a respeito, D'Ors, Derecho Privado..., cit. (nota 3 supra), p. 298 e Jörs \& Kunkel, Derecho Privado..., cit. (nota 3 supra), p. 382. 
sempre para o pater, sendo que, por outro lado, era considerado capaz de se obrigar, justamente em razão da possibilidade de vir a adquirir bens por sucessão.

Esta solução revelava-se mais iníqua ainda nos casos do filho emancipatus, do exheredatus e do abstentus, ${ }^{58}$ pois neles o filho iniciava sua vida independente sem nenhum patrimônio. ${ }^{59}$

Nesses três casos, o pretor, causa cognita, determinava que sua condenação, pelos débitos contraídos in potestate, fosse limitada ao id quod facere potest.

No exercício de seu poder discricionário, o magistrado considerava diversas circunstâncias; antes de mais nada, a origem dos débitos, concedendo o benefício somente no caso de dívidas contratuais. Pelos débitos decorrentes de delito o filho, de acordo com Ulpiano, 29 ed., D. 14, 5, 4, 2, responderia in solidum. ${ }^{60}$

A concessão do benefício também se excluía quando o filho devedor tivesse agido com dolo, como aconteceria, por exemplo, se se tivesse feito passar por pater familias para obter um crédito. ${ }^{61}$

A discricionariedade para conceder causa cognita o benefício levava o pretor, ainda, a negá-lo quando o filho viesse a ser demandado após um tempo suficientemente longo para the permitir a constituição de um patrimônio.

58. Cf. Guarino, La condanna..., cit. (nota 15 supra), p. 43

59. No Direito clássico, o emancipado saía da família de origem, perdendo todos os seus direitos nela, inclusive o sucessório. No Direito justinianeu, a emancipação apenas subtraia o filius familias da patria potestas, sem prejuizo do direito à herança. Cf., a respeito, Moreira Alves, Direito Romano..., cit. (nota 3 supra), v. 2, p. 239. De acordo com Talamanca, Istituzioni..., cit. (nota 55 supra), p. 130, a emancipação extinguia as dividas contraídas pelo fillho enquanto in potestate. Contudo, o credor poderia conseguir do magistrado uma ação honorária contra o emancipado, depois de avaliadas as circunstâncias e concedido o beneficium competentice. O filho, heres necessarius, mesmo recebendo herança gravosa, não poderia iure civile recusá-la, ficando, em teoria, exposto à bonorum venditio e à infamia, por conta dos débitos não-só seus como também dos paternos. Visando evitar que o filho fosse responsabilizado pelas dívidas do de cujus, o pretor introduziu o instituto da abstenção pelo qual - filho se livrava dos credores paternos desde que se abstivesse da prática de atos que o caracterizassem como herdeiro. Cf. Guarino, La condanna.., cit. (nota 15 supra), p. 45.

60. Ulp. 29 ed., D. 14, 5, 4, 2: Quamquam autem ex contractu in id quod facere potest actio in eum datur, tumen ex delictis in solidum convenietur.

[Mesmo que em virtude de contrato se dê ação contra o devedor até onde possa pagar, contudo, em se tratando de delitos sua responsabilidade será integral].

61. Cf., nesse sentido, Ulp. 29 ed., D. 14, 5, 4, 1; Ulp. 2 disput., D. 14, 5, 6; e Marcell. 2 dig., D. $42,1,10$. 
É o que afirma Ulpiano, 29 ed., D. 14, 5, 4, 4:

Sed an etiam temporis haberi debeat ratio, ut, si quidem ex continenti cum filio agatur, detur actio in id quod facere potest, sin vero post multos annos, non debeat indulgeri? et mihi videtur rationem habendam esse: in hoc enim causae cognitio vertitur.

[Dever-se-á também levar por acaso em conta o tempo transcorrido para que, se se demanda o filho imediatamente após a realização do negócio, se dê ação contra ele até onde possa pagar, não se tendo a mesma indulgência se for demandado após muitos anos? Parece-me que sim, e é isto que significa a expressão conhecimento de causa.]

Pela mesma razão, o filho emancipado que, após a morte do pai, herdasse mediante a bonorum possessio pretoriana, não-gozaria do benefício por decisão do magistrado. ${ }^{62}$

A nosso ver, a denegação pelo pretor, causa cognita, do benefício em todos esses casos obedece a plausíveis razões de eqüidade.

$O$ benefício introduzido inicialmente em favor dos filhos emancipati, exheredati e dos abstenti, foi analogicamente estendido pela jurisprudência clássica e pós-clássica a diversos outros casos.

O primeiro deles foi o do filho libertado após uma noxae deditio. Para Levet, a analogia com a situação do emancipado era tal que teria justificado plenamente a concessão da condenação limitada. ${ }^{63}$

Outro caso era o do filho que se tornava sui iuris independentemente de emancipação, em virtude da elevação à dignidade de Flamen Dialis, de servidor do deus do Estado. Subtraindo-se da patria potestas, o flâmine saía de sua família sem nada adquirir do patrimônio paterno. De acordo com Ulpiano, 29 ed., D. 14, 5, 2, 1, também neste caso o devedor seria condenado apenas in id quod facere potest, pelas dívidas contraídas enquanto in potestate.

No mesmo texto, Ulpiano menciona o caso do filho dado em adoção. Enquanto permanecesse in adoptiva familia e sob o poder do pai adotivo, não

62. Cf. Levet, Le bénéfice..., cit. (nota 2 supra), p. 66, nota 19.

63. Cf. Le bénéfice..., cit. (nota 2 supra), p. 68. A analogia não se limitava à concessão do beneficio. Assim como ao emancipado, àquele que sofrera a noxae deditio o pretor concedia, conforme o caso. a bonorum possessio contra labulas ou unde liberi. 
poderia ser executado, mas uma vez extinta a adoção gozaria, como o emancipado, do beneficium pelas dívidas contraídas, enquanto in potestate do pai natural ou do adotivo. ${ }^{64}$

Ainda em Ulp. 29 ed., D. 14, 5, 2, 1 se conhece o caso do filho não propriamente deserdado pelo pai, mas que recebe deste uma quota hereditária praticamente nula (ex parte mínima). De acordo com Guarino, ${ }^{65}$ Cervídio Scévola, cinqüenta anos antes de Ulpiano, teria tido opinião diferente a julgar pelas palavras do jurisconsulto em 1 resp., D. 14, 5, 7:

Pater filio permisit mutuam pecuniam accipere et per epistulam creditori mandavit, ut ei crederet: filius ex minima parte patri heres existitit. respondi esse in potestate creditoris, utrum filium, cui credidisset, in solidum, an heredes, pro qua parte quisque successisset, mallet convenire: <sed filius condemnatur in quantum facere potest>.

[Um pai permitiu ao filho receber dinheiro emprestado, autorizando por carta o mútuo. O filho foi instituído herdeiro do pai em mínima parte. Respondi que, se quisesse, o credor poderia demandar pelo todo aquele filho ao qual tinha emprestado, ou seus herdeiros pela parte que cada um tivesse herdado; mas o filho deve ser condenado até onde puder pagar.]

As palavras finais do texto (sed filius condemnatur in quantum facere potest) representam, segundo Guarino, interpolação justinianéia, visando modificar a decisão no sentido do pensamento de Ulpiano. ${ }^{66}$

64. Causa-nos estranheza, data venia, a exegese que Levet, Le bénéflce..., cit. (nota 2 supra), pp. 69-71, faz do referido passo. Para o monografista francês a situação analisada pelo texto seria a do filho que, tendo-se obrigado por contrato enguanto in patria potestate, tivesse sido dado em adoção. Mais tarde, morto seu pai natural, ao ser demandado, enquanto in adoptiva familia, por aqueles seus credores, estes obteriam condenação somente in id quod facere potest. Esta é a solução que, na exegese de Levet, o texto oferece, solução com a qual ele não concorda por considerar que o filho adotivo não poderia ser acionado pelos credores. Contudo, em nossa opinião, a situação descrita pelo texto não é bem essa; é muito mais singela: ela apresenta simplesmente o fillho adotivo em situação análoga à do filho in patria potestate, e a ele oferece a mesma vantagem gozar do beneficio no momento da cessação da potestas adotiva (sed et si...sui iuris factus sit).

65. Cf. La condanna..., cit. (nota 15 supra), p. 47.

66. A opinião de UIpiano, favorável à concessão do beneficio ao filho herdeiro ex minima parte, também clara em Ulp. 29 ed., D. 14, 5, 4 pr., no qual o jurisconsulto afirma que, no caso de filho que recebe parte considerável da herança, o problema da condenação limitada não se apresenta, restando 
Mais tarde, a reforma de Justiniano teria estendido a aplicação do benefício, cognita causa, mesmo ao fillho instituído herdeiro numa parte apreciável da herança.

Levet propõe a questão de saber qual seria o significado da expressão ex minima parte utilizada por Ulpiano e Scévola. Para ele, essa mínima parte deveria ser entendida em relação ao total das dívidas contraídas pelo filho e não à quarta parte dos bens que o pai era obrigado a deixar ao fillho por força da legítima. Nesse sentido é que, em sua opinião, se deve entender, o texto de Ulpiano, 29 ed., D. 14, 5, 4 pr., no qual o jurista diz que mesmo no caso de o filho ser instituído herdeiro ex parte non modica, o pretor, conforme os casos, poderia conceder-lhe o benefício.

Finalmente, qual a ratio que teria determinado a concessão do benefício aos emancipati, exheredati, abstenti e em outros casos análogos? Para Levet, ${ }^{67}$ a razão teria sido o desejo de o pretor evitar a injustiça que resultaria da possibilidade de expor à execução pessoal o filho que, após se tornar sui iuris, não recebera nenhum patrimônio do pater com o qual pudesse enfrentar as dívidas, sendo que durante toda a sua vida in potestate adquirira para este.

Assim, no Direito clássico, sempre que um filho fosse emancipado pelo seu pai, natural ou adotivo, se tornasse Flamen Dialis ou fosse manumitido por seu quasi dominus, toda vez que um filho fosse deserdado ou instituído herdeiro ex parte minima, ou tivesse feito uso do ius abstinendi, o pretor, em princípio mas sempre causa cognita, concedia-Ihe o beneficium competentiae. Recusá-lo-ia, contudo, se após emancipado, e sobrevindo a morte do pai, o filho viesse a obter parte na sucessão mediante a bonorum possessio, já que o pretor se reservava sempre o direito de apreciar cada caso.

Este sistema, que no direito do início do Império possuía certa harmonia, foi perdendo pouco a pouco sua coerência a partir da introdução do peculium castrense. Com efeito, se os credores do filho, mesmo in potestate, podiam executá-lo sobre os bens do pecúlio, que sentido teria condená-lo apenas in id quod facere potest após. a extinção da potestas? Que injustiça haveria em perseguir in solidum um devedor que, no tocante ao pecúlio, não aumentara o patrimônio paterno? Para Levet $^{68}$ não haveria razão para impedir que, uma vez extinta a

ao credor a opção entre demandá-lo pelo total do crédito ou pela quota hereditária recebida. Cf., também, Solazzi, L'estinzione..., cit. (nota 15 supra), p. 206.

67. Cf. Le bénéfice..., cit. (nota 2 supra), p. 74.

68. Cf. Le bénéfice..., cit. (nota 2 supra), p. 75. 
potestas, se cobrassem in solidum os créditos relativos a uma massa de bens - o pecúlio , da qual o filho não era privado nem pela emancipação, nem pela deserdação e nem pelo exercício do ius abstinendi.

Finalmente, na medida em que no Direito pós-clássico avançado o filho passou a adquirir para si, ele poderia ser executado nos seus bens como se pater familias fosse, não havendo mais razão para limitar o direito dos credores do filho emancipado, deserdado ou que se abstivera da herança. ${ }^{69}$

São Paulo, setembro de 1998.

69. Como, entretanto, a condenação in id quod facere potest em favor do fillho emancipado continua na legislação justinianéia, Levet, Le bénéfice..., cit. (nota 2 supra), p. 78, entende que isto só ocorreria no caso em que o filho tivesse adquirido bens e contraido dividas ex re patris. De acordo com Inst. 2, 9, 1, os bens, nesse caso, reverteriam ao pater, enquanto o filho responderia pelas dividas contraídas. Em tal situação concreta é que teria aplicação o benefício, o que parece justo. 